Supplement of Atmos. Chem. Phys., 20, 4787-4807, 2020

https://doi.org/10.5194/acp-20-4787-2020-supplement

(C) Author(s) 2020. This work is distributed under

the Creative Commons Attribution 4.0 License.

(c) (i)

Supplement of

\title{
Trends and emissions of six perfluorocarbons in the Northern Hemisphere and Southern Hemisphere
}

Elise S. Droste et al.

Correspondence to: Elise S. Droste (e.droste@uea.ac.uk)

The copyright of individual parts of the supplement might differ from the CC BY 4.0 License. 


\section{Contents}

1 Additional Calibration Details 22

2 Ion Ratios $\quad 3$

3 Perfluorocarbon Ratios $\quad 5$

$\begin{array}{llll}5 & 4 & \text { Uncertainties } & 6\end{array}$

5 NAME Footprints and CO Emissions $\quad 7$

6 Global Emission Rates $\quad 8$

7 Correlations of PFC Mixing Ratios in Taiwan $\quad 9$ 


\section{Additional Calibration Details}

Even though the current method has separated the isomers for $\mathrm{C}_{4} \mathrm{~F}_{10}$, the i- $\mathrm{C}_{4} \mathrm{~F}_{10}$ isomer can currently not be quantified yet, because, apart from having a very small signal, its main quantifying ion is not well separated from one of the quantifying ions for $\mathrm{n}-\mathrm{C}_{4} \mathrm{~F}_{10}$. Even if we were able to separate it completely, it would also have to be calibrated using a pure $\mathrm{i}-\mathrm{C}_{4} \mathrm{~F}_{10}$ reagent,

5 which we were unable to acquire. Hence, we are unable to quantify what fraction of the $2.8 \%$ (which is the relative difference between the UEA2010 and UEA2018 calibration scales for $n-C_{4} F_{10}$ ) is due to leak-tightness and to the influence of i- $C_{4} F_{10}$.

The overall volume uncertainty of the sample loops that were filled with pure compounds during both dilution steps is $5 \%$, as has been outlined in Laube et al. (2010). This is the likeliest and highest source of uncertainty in the entire calibration procedure. As has been shown in multiple previous papers (Laube et al., 2010, 2012, 2014, 2016; Oram et al., 2012; Kloss et al., 2014), the overall calibration uncertainty is very likely about $7 \%$. Our measurements fall well within that envelope.

Table S1. Mixing ratios (in parts per trillion) determined for the diluted, high purity PFC compounds and CFC-11 as the reference compound.

\begin{tabular}{|c|c|c|c|c|}
\hline Calibration No. & $\mathrm{n}-\mathrm{C}_{4} \mathrm{~F}_{10} / \mathrm{CFC}-11$ & $\mathrm{i}-\mathrm{C}_{6} \mathrm{~F}_{14} / \mathrm{CFC}-11$ & $\mathrm{n}-\mathrm{C}_{6} \mathrm{~F}_{14} / \mathrm{CFC}-11$ & $\mathrm{n}-\mathrm{C}_{7} \mathrm{~F}_{16} / \mathrm{CFC}-11$ \\
\hline 1 & $9 / 24.7$ & $5.9 / 22.3$ & $7.1 / 27.3$ & $5.8 / 23.6$ \\
\hline 2 & $8.6 / 29.3$ & $8.9 / 25.3$ & $5.0 / 24.7$ & $6.8 / 25.3$ \\
\hline 3 & $9.8 / 22.4$ & $5.1 / 22.4$ & $8.9 / 25.3$ & $4.8 / 29.3$ \\
\hline
\end{tabular}




\section{Ion Ratios}

The ratio of the two main quantifying ions for $\mathrm{C}_{6} \mathrm{~F}_{14}$ and $\mathrm{C}_{7} \mathrm{~F}_{16}(\mathrm{~m} / z, 169.0$ and 219.0) is used to determine whether all isomers have been separated for a particular peak in the chromatograph. Deviation of the ratio measured in the Cape Grim samples from the ratio measured in the calibration samples, which are composed of highly purified isomers, indicates the possibility

5 that not all isomers have been separated during gas-chromatography.

For $\mathrm{i}-\mathrm{C}_{6} \mathrm{~F}_{14}$, the average ion ratio in the calibration is $0.89 \pm 0.03$ and Cape Grim air samples have an ion ratio that is on average $1.00 \pm 0.07$ (Fig. S1 A). The positive offset of the Cape Grim ion ratio to the calibration ion ratio for i- $\mathrm{C}_{6} \mathrm{~F}_{14}$ seems to be consistent. $\mathrm{n}-\mathrm{C}_{6} \mathrm{~F}_{14}$ measured in air samples have an average ion ratio of $0.99 \pm 0.03$, which is consistently - but not significantly - lower than the ion ratio for the calibrations (1.04 \pm 0.07 ) (Fig. S1 B). Finally, $\mathrm{n}_{-} \mathrm{C}_{7} \mathrm{~F}_{16}$ has an average ion ratio of $1.00 \pm 0.05$ in the Cape Grim air samples, which agrees very well with the average ion ratio in its calibration: $1.02 \pm 0.07$ (Fig. S1 C). Overall, the difference between the ion ratios of the air samples and the calibrations is not significant within the uncertainties, especially for $\mathrm{n}-\mathrm{C}_{6} \mathrm{~F}_{14}$ and $\mathrm{n}-\mathrm{C}_{7} \mathrm{~F}_{16}$. Even though this means that it is highly likely that only one isomer is being measured instead of multiple under one peak, the possibility that not all isomers within this peak have been separated cannot be excluded.

15 A limitation is that a trend analysis of the ion ratio for these PFC isomers is not possible here, since problems with baseline distortions in the Cape Grim data resulted in a lack of samples before 2005 that have good precisions on both $\mathrm{m} / z, 219.0$ and 169.0 ions. This is especially the case for the $\mathrm{m} / z 219$ ion, which generally exhibits smaller peaks than the $\mathrm{m} / z .169$ ion and also has a noisier baseline in our analytical system. 

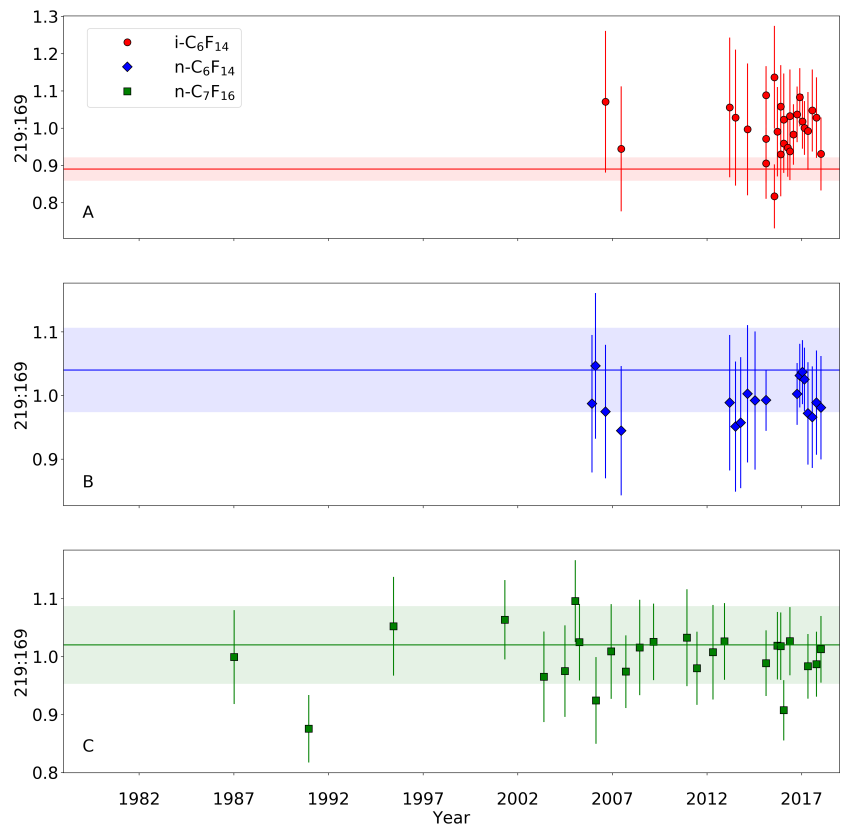

Figure S1. Ratios of ions $m / z, 219: 169$ for i- $\mathrm{C}_{6} \mathrm{~F}_{14}(\mathrm{~A}), \mathrm{n}-\mathrm{C}_{6} \mathrm{~F}_{14}(\mathrm{~B})$, and $\mathrm{n}-\mathrm{C}_{7} \mathrm{~F}_{16}$ (C) for Cape Grim air samples between 1987 and 2018. Note that both ions could only be measured with high precision for samples collected after 2005 for i- $\mathrm{C}_{6} \mathrm{~F}_{14}$ and n- $\mathrm{C}_{6} \mathrm{~F}_{14}$. The horizontal line illustrates the average 219:169 ion ratio of the calibrations done in the current work. Shaded area indicates the propagated uncertainty of the average 219:169 ratio of the calibrations. 


\section{Perfluorocarbon Ratios}

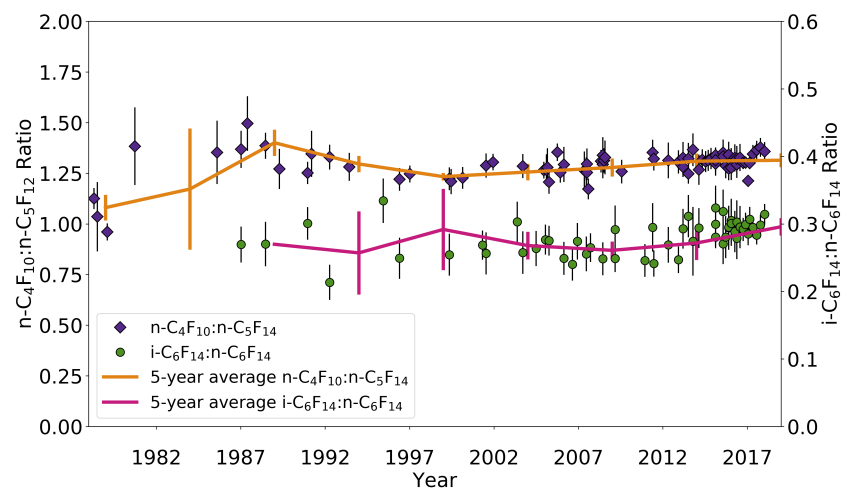

Figure S2. Ratio of $\mathrm{n}-\mathrm{C}_{4} \mathrm{~F}_{10}: \mathrm{n}-\mathrm{C}_{5} \mathrm{~F}_{12}$ (diamonds) and i- $\mathrm{C}_{6} \mathrm{~F}_{14}: \mathrm{n}-\mathrm{C}_{6} \mathrm{~F}_{14}$ (circles) mixing ratios measured in Cape Grim samples between 1978 and 2018. Error bars indicate propagated measurement uncertainties. Full orange and magenta lines illustrate respective five-year averages of the ratios, with error bars comprising the propagated measurement uncertainties. 


\section{Uncertainties}

Table S2. Average analytical uncertainties, average model-fit uncertainties, calibration uncertainty, trend uncertainties (composed of the average analytical uncertainty, the average best-fit uncertainty, and the model transport uncertainty of $5 \%$ ) and total uncertainties (composed as the trend uncertainty and calibration uncertainty) for all PFCs. The total uncertainties for $\mathrm{c}-\mathrm{C}_{4} \mathrm{~F}_{8}$ and $\mathrm{n}-\mathrm{C}_{5} \mathrm{~F}_{12}$ also includes an uncertainty related to the error in the conversion of the mixing ratio between two internal working standards: $0.58 \%$ and $1.98 \%$, respectively.

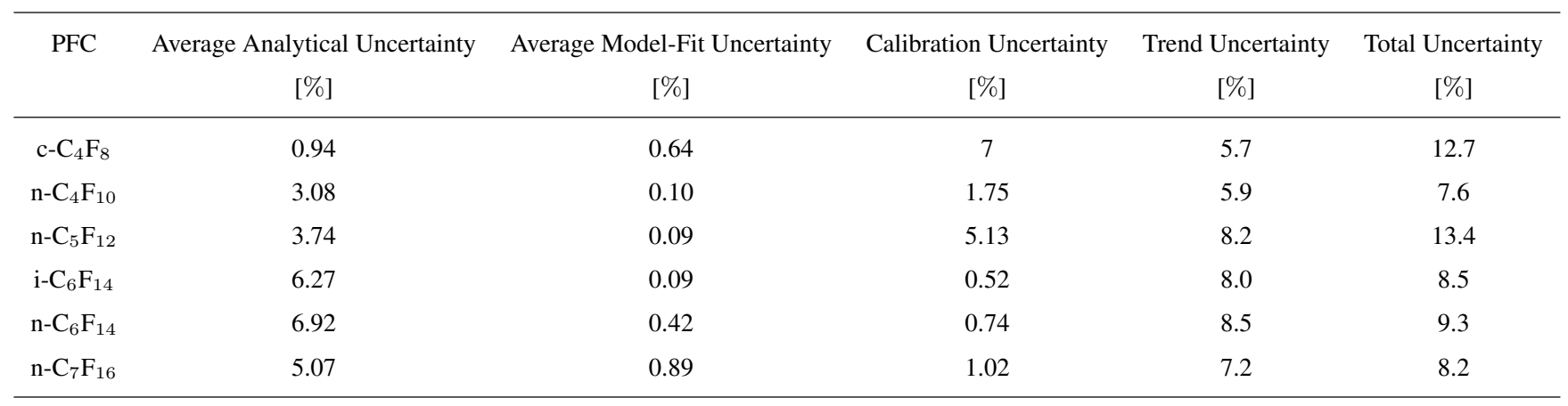




\section{NAME Footprints and CO Emissions}

The following explains the calculations used to derive modelled CO mixing ratios, using the NAME model's footprints.

The dilution factor $(n)$ is determined for air masses in each grid cell. The dilution factor relates to the amount of time that a particle spends in each grid cell for each $100 \mathrm{~m}$ of grid cell depth. Equation 1 shows how the dilution factor (unit: $\mathrm{s} \mathrm{m}^{-1}$ ) is

5 calculated:

$n=\frac{P}{m} \cdot S$

where $P$ is the particle mass density residence time in $\mathrm{g} \mathrm{s} \mathrm{m}^{-3}, m$ is the mass of the particle emitted in $\mathrm{g}$, and $S$ is the surface area of each grid cell in $\mathrm{m}^{2}$. The modelled mixing ratios of $\mathrm{CO}$ are calculated by combining the output of Equation 1 (i.e. the dilution factor) with the distribution of the emissions, which are taken from the Representative Concentration Pathway 10 (Riahi et al., 2011; Van Vuuren et al., 2011) (http://tntcat.iiasa.ac.at:8787/RcpDb/dsd?Action=htmlpage\&page=welcome). This is represented in Equation 2, where $E$ is the emission estimates of $\mathrm{CO}$ in $\mathrm{g} \mathrm{m}^{-2} \mathrm{~s}^{-1}, Z$ refers to any of the sectors applicable to this model (industry, power plants, solvents, agricultural waste burning, waste, forest burning, grassland burning, residential, international shipping, surface transportation, or agriculture), $M_{C O}$ is the molar mass in $\mathrm{g} \mathrm{mol}^{-1}, x$ is the number of grid cells, and $C O_{Z}$ is the modelled concentration of $\mathrm{CO}$ emitted from sector $Z$ in mol m${ }^{-3}$, which is converted to mol mol ${ }^{-1}$ using the gas law with temperature and pressure data.

$\sum^{x} \frac{E_{Z} \cdot n}{M_{C O}}=C O_{Z}$

Both $E_{Z}$ and $n$ match two dimensional (lat-lon) grids. For each grid cell, $E_{Z}$ and $n$ are combined to get a contribution to the modelled mixing ratio from emissions in that grid cell, which are converted to mixing ratios using the number of moles of air per volume. Those contributions are summed for all grid cells $(x)$ to obtain $C O_{Z}$. 
Table S3. Global annual emission rates $\left(\mathrm{Gg} \mathrm{yr}^{-1}\right)$ for all six PFCs used in the model simulations to obtain the best fit of the simulated model mixing ratios to the measured mixing ratios in Cape Grim.

\begin{tabular}{|c|c|c|c|c|c|c|}
\hline Year & $\mathrm{c}-\mathrm{C}_{4} \mathrm{~F}_{8}$ & n- $C_{4} \mathrm{~F}_{10}$ & n- $C_{5} \mathrm{~F}_{12}$ & i- $\mathrm{C}_{6} \mathrm{~F}_{14}$ & n- $C_{6} \mathrm{~F}_{14}$ & $\mathrm{n}-\mathrm{C}_{7} \mathrm{~F}_{16}$ \\
\hline 1978 & 0.910 & 0.140 & 0.110 & 0.030 & 0.153 & 0.048 \\
\hline 1979 & 0.935 & 0.160 & 0.120 & 0.030 & 0.155 & 0.048 \\
\hline 1980 & 0.970 & 0.178 & 0.130 & 0.030 & 0.159 & 0.048 \\
\hline 1981 & 1.030 & 0.186 & 0.140 & 0.030 & 0.160 & 0.075 \\
\hline 1982 & 1.110 & 0.194 & 0.150 & 0.030 & 0.162 & 0.100 \\
\hline 1983 & 1.20 & 0.202 & 0.160 & 0.030 & 0.164 & 0.120 \\
\hline 1984 & 1.328 & 0.210 & 0.170 & 0.030 & 0.166 & 0.140 \\
\hline 1985 & 1.476 & 0.218 & 0.190 & 0.030 & 0.170 & 0.183 \\
\hline 1986 & 1.673 & 0.226 & 0.208 & 0.035 & 0.170 & 0.183 \\
\hline 1987 & 1.476 & 0.234 & 0.220 & 0.035 & 0.170 & 0.183 \\
\hline 1988 & 1.230 & 0.242 & 0.233 & 0.035 & 0.170 & 0.183 \\
\hline 1989 & 0.984 & 0.254 & 0.245 & 0.035 & 0.170 & 0.183 \\
\hline 1990 & 0.787 & 0.264 & 0.258 & 0.035 & 0.170 & 0.183 \\
\hline 1991 & 0.590 & 0.272 & 0.270 & 0.035 & 0.170 & 0.183 \\
\hline 1992 & 0.443 & 0.279 & 0.284 & 0.119 & 0.170 & 0.183 \\
\hline 1993 & 0.394 & 0.283 & 0.300 & 0.150 & 0.170 & 0.183 \\
\hline 1994 & 0.394 & 0.284 & 0.310 & 0.180 & 0.250 & 0.183 \\
\hline 1995 & 0.445 & 0.285 & 0.318 & 0.230 & 1.150 & 0.183 \\
\hline 1996 & 0.500 & 0.286 & 0.315 & 0.250 & 1.200 & 0.183 \\
\hline 1997 & 0.555 & 0.287 & 0.285 & 0.250 & 1.210 & 0.183 \\
\hline 1998 & 0.610 & 0.284 & 0.243 & 0.190 & 0.900 & 0.183 \\
\hline 1999 & 0.665 & 0.274 & 0.220 & 0.168 & 0.653 & 0.183 \\
\hline 2000 & 0.720 & 0.240 & 0.197 & 0.145 & 0.470 & 0.183 \\
\hline 2001 & 0.775 & 0.200 & 0.173 & 0.120 & 0.395 & 0.183 \\
\hline 2002 & 0.830 & 0.170 & 0.150 & 0.105 & 0.358 & 0.183 \\
\hline 2003 & 0.895 & 0.140 & 0.120 & 0.093 & 0.330 & 0.183 \\
\hline 2004 & 0.950 & 0.118 & 0.095 & 0.088 & 0.311 & 0.183 \\
\hline 2005 & 1.005 & 0.110 & 0.080 & 0.085 & 0.293 & 0.183 \\
\hline 2006 & 1.060 & 0.103 & 0.075 & 0.085 & 0.267 & 0.183 \\
\hline 2007 & 1.115 & 0.098 & 0.070 & 0.085 & 0.243 & 0.183 \\
\hline 2008 & 1.170 & 0.095 & 0.065 & 0.085 & 0.218 & 0.183 \\
\hline 2009 & 1.225 & 0.093 & 0.060 & 0.085 & 0.199 & 0.183 \\
\hline 2010 & 1.280 & 0.092 & 0.058 & 0.085 & 0.179 & 0.183 \\
\hline 2011 & 1.335 & 0.092 & 0.057 & 0.085 & 0.160 & 0.183 \\
\hline 2012 & 1.390 & 0.092 & 0.057 & 0.085 & 0.150 & 0.183 \\
\hline 2013 & 1.470 & 0.092 & 0.057 & 0.085 & 0.141 & 0.183 \\
\hline 2014 & 1.570 & 0.092 & 0.057 & 0.085 & 0.141 & 0.183 \\
\hline 2015 & 1.670 & 0.092 & 0.057 & 0.085 & 0.141 & 0.183 \\
\hline 2016 & 1.779 & 0.092 & 0.057 & 0.085 & 0.141 & 0.183 \\
\hline 2017 & 1.900 & 0.092 & 0.057 & 0.085 & 0.141 & 0.183 \\
\hline
\end{tabular}



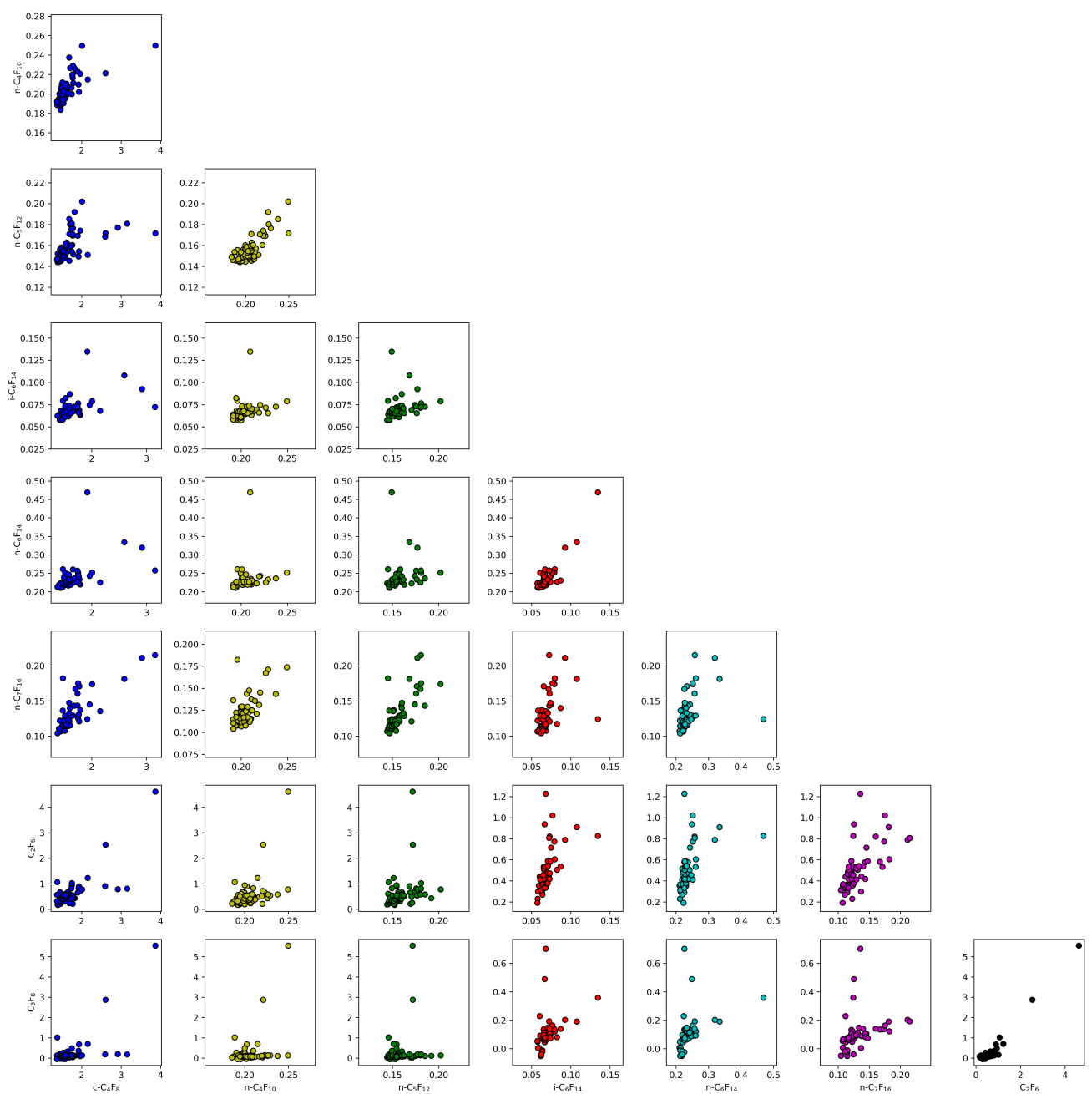

Figure S3. Correlations of all PFC mixing ratios (ppt) measured in Taiwan. 
Table S4. R-squared Spearman correlation coefficients for correlation analysis between all PFCs in this study. All values are significant (p-value $<0.05)$.

\begin{tabular}{|c|c|c|c|c|c|c|c|}
\hline & $\mathrm{c}-\mathrm{C}_{4} \mathrm{~F}_{8}$ & $\mathrm{n}-\mathrm{C}_{4} \mathrm{~F}_{10}$ & $\mathrm{n}-\mathrm{C}_{5} \mathrm{~F}_{12}$ & $\mathrm{i}-\mathrm{C}_{6} \mathrm{~F}_{14}$ & $\mathrm{n}-\mathrm{C}_{6} \mathrm{~F}_{14}$ & $\mathrm{n}-\mathrm{C}_{7} \mathrm{~F}_{16}$ & $\mathrm{C}_{2} \mathrm{~F}_{6}$ \\
\hline $\mathrm{n}-\mathrm{C}_{4} \mathrm{~F}_{10}$ & 0.62 & & & & & & \\
\hline $\mathrm{n}-\mathrm{C}_{5} \mathrm{~F}_{12}$ & 0.56 & 0.45 & & & & & \\
\hline $\mathrm{i}-\mathrm{C}_{6} \mathrm{~F}_{14}$ & 0.35 & 0.20 & 0.32 & & & & \\
\hline $\mathrm{n}-\mathrm{C}_{6} \mathrm{~F}_{14}$ & 0.35 & 0.20 & 0.33 & 0.40 & & & \\
\hline $\mathrm{n}-\mathrm{C}_{7} \mathrm{~F}_{16}$ & 0.55 & 0.23 & 0.49 & 0.33 & 0.39 & & \\
\hline $\mathrm{C}_{2} \mathrm{~F}_{6}$ & 0.42 & 0.21 & 0.28 & 0.52 & 0.52 & 0.54 & \\
\hline $\mathrm{C}_{3} \mathrm{~F}_{8}$ & 0.35 & 0.14 & 0.20 & 0.39 & 0.50 & 0.46 & 0.68 \\
\hline
\end{tabular}

Table S5. R-squared Spearman correlation coefficients for correlation analysis between all PFCs in this study and the particle density per region derived from NAME model results. Significance is indicated by * ( $\mathrm{p}$-value $<0.05$ ).

\begin{tabular}{lllllllll}
\hline & $\mathrm{c}-\mathrm{C}_{4} \mathrm{~F}_{8}$ & $\mathrm{n}-\mathrm{C}_{4} \mathrm{~F}_{10}$ & $\mathrm{n}-\mathrm{C}_{5} \mathrm{~F}_{12}$ & $\mathrm{i}-\mathrm{C}_{6} \mathrm{~F}_{14}$ & $\mathrm{n}-\mathrm{C}_{6} \mathrm{~F}_{14}$ & $\mathrm{n}-\mathrm{C}_{7} \mathrm{~F}_{16}$ & $\mathrm{C}_{2} \mathrm{~F}_{6}$ & $\mathrm{C}_{3} \mathrm{~F}_{8}$ \\
\hline East China & $0.33^{*}$ & $0.20^{*}$ & $0.47^{*}$ & $0.33^{*}$ & $0.19^{*}$ & $0.49^{*}$ & $0.19^{*}$ & $0.10^{*}$ \\
North China & $0.02^{*}$ & 0.03 & $0.10^{*}$ & 0.02 & 0.01 & $0.07^{*}$ & 0.00 & 0.00 \\
North -East China & 0.02 & 0.01 & 0.01 & 0.02 & 0.01 & 0.00 & 0.01 & 0.00 \\
North-West China & 0.06 & 0.00 & 0.00 & 0.06 & 0.01 & 0.01 & 0.00 & 0.03 \\
South-Central China & $0.14^{*}$ & $0.09^{*}$ & $0.21^{*}$ & $0.14^{*}$ & 0.07 & $0.11^{*}$ & $0.13^{*}$ & 0.05 \\
South-West China & 0.01 & 0.00 & 0.00 & 0.01 & 0.00 & 0.02 & 0.02 & 0.02 \\
Indo-China & 0.00 & 0.01 & 0.00 & 0.00 & 0.00 & 0.01 & 0.03 & $0.05^{*}$ \\
Philippines & 0.03 & 0.01 & 0.01 & 0.03 & 0.05 & 0.01 & 0.04 & 0.01 \\
Taiwan & 0.00 & 0.00 & 0.03 & 0.00 & 0.02 & 0.02 & 0.02 & 0.04 \\
Japan & 0.01 & 0.01 & 0.01 & 0.01 & 0.01 & 0.00 & 0.00 & 0.01 \\
Korea & $0.08^{*}$ & 0.00 & 0.01 & $0.08^{*}$ & $0.14^{*}$ & 0.06 & $0.07^{*}$ & 0.01 \\
East China Sea & $0.19^{*}$ & $0.12^{*}$ & $0.33^{*}$ & $0.19^{*}$ & $0.27^{*}$ & $0.21^{*}$ & $0.12^{*}$ & $0.07^{*}$ \\
Japan Sea & 0.05 & 0.00 & 0.00 & 0.05 & 0.06 & 0.02 & 0.03 & 0.00 \\
Pacific Ocean & 0.03 & 0.01 & $0.06^{*}$ & 0.03 & 0.02 & 0.05 & 0.00 & 0.01 \\
South China Sea & 0.03 & 0.00 & 0.00 & 0.03 & 0.00 & 0.00 & $0.06^{*}$ & $0.05^{*}$ \\
\hline
\end{tabular}


Table S6. R-squared Spearman correlation coefficients for correlation analysis between all PFCs in this study and the CO mixing ratio derived from the NAME model results per CO source type. Significance is indicated by ${ }^{*}$ (p-value $<0.05$ ). Industry includes combustion and processing; power plants include energy generation, energy conversion, and extraction; waste includes landfills, waste water, and waste incineration; residential includes domestic and commercial residences; and agriculture includes animal husbandry, rice crops, and soil.

\begin{tabular}{lllllllll}
\hline & $\mathrm{c}-\mathrm{C}_{4} \mathrm{~F}_{8}$ & $\mathrm{n}-\mathrm{C}_{4} \mathrm{~F}_{10}$ & $\mathrm{n}-\mathrm{C}_{5} \mathrm{~F}_{12}$ & $\mathrm{i}-\mathrm{C}_{6} \mathrm{~F}_{14}$ & $\mathrm{n}_{-} \mathrm{C}_{6} \mathrm{~F}_{14}$ & $\mathrm{n}_{-} \mathrm{C}_{7} \mathrm{~F}_{16}$ & $\mathrm{C}_{2} \mathrm{~F}_{6}$ & $\mathrm{C}_{3} \mathrm{~F}_{8}$ \\
\hline Industry & $0.45^{*}$ & $0.21^{*}$ & $0.48^{*}$ & $0.34^{*}$ & $0.25^{*}$ & $0.48^{*}$ & $0.28^{*}$ & $0.21^{*}$ \\
Power Plants & $0.41^{*}$ & $0.13^{*}$ & $0.27^{*}$ & $0.31^{*}$ & $0.26^{*}$ & $0.37^{*}$ & $0.34^{*}$ & $0.31^{*}$ \\
Solvents & $0.39^{*}$ & $0.21^{*}$ & $0.50^{*}$ & $0.30^{*}$ & $0.20^{*}$ & $0.44^{*}$ & $0.19^{*}$ & $0.12^{*}$ \\
Agricultural Waste Burning & $0.33^{*}$ & $0.18^{*}$ & $0.41^{*}$ & $0.26^{*}$ & $0.18^{*}$ & $0.41^{*}$ & $0.18^{*}$ & $0.08^{*}$ \\
Waste & 0.04 & 0.00 & 0.00 & 0.03 & $0.14^{*}$ & 0.04 & $0.06^{*}$ & 0.01 \\
Forest Burning & 0.00 & 0.00 & 0.01 & 0.01 & 0.02 & 0.00 & 0.00 & 0.01 \\
Grassland Burning & 0.01 & 0.00 & 0.01 & 0.01 & 0.01 & 0.02 & 0.00 & 0.00 \\
Residential & $0.42^{*}$ & $0.2^{*}$ & $0.45^{*}$ & $0.33^{*}$ & $0.22^{*}$ & $0.46^{*}$ & $0.25^{*}$ & $0.17^{*}$ \\
International Shipping & 0.01 & 0.00 & 0.00 & 0.00 & 0.02 & 0.00 & 0.04 & $0.05^{*}$ \\
Surface Transportation & $0.16^{*}$ & 0.02 & 0.03 & $0.10^{*}$ & $0.08^{*}$ & $0.08^{*}$ & $0.17^{*}$ & $0.19^{*}$ \\
Agriculture & 0.00 & 0.01 & 0.01 & 0.00 & 0.00 & 0.01 & 0.00 & 0.01 \\
\hline
\end{tabular}




\section{References}

Kloss, C., Newland, M. J., Oram, D. E., Fraser, P. J., Brenninkmeijer, C. A. M., Röckmann, T., and Laube, J. C.: Atmospheric abundances, trends and emissions of CFC-216ba, CFC-216ca and HCFC-225ca, Atmosphere, 5, 420-434, https://doi.org/10.3390/atmos5020420, 2014.

5 Laube, J., Hogan, C., Newland, M., Mani, F. S., Fraser, P., Brenninkmeijer, C., Martinerie, P., Oram, D., Röckmann, T., Schwander, J., et al.: Distributions, long term trends and emissions of four perfluorocarbons in remote parts of the atmosphere and firn air, Atmospheric chemistry and physics, 12, 4081-4090, https://doi.org/10.5194/acp-12-4081-2012, 2012.

Laube, J. C., Martinerie, P., Witrant, E., Blunier, T., Schwander, J., Brenninkmeijer, C., Schuck, T. J., Bolder, M., Röckmann, T., Veen, C., et al.: Accelerating growth of HFC-227ea (1, 1, 1, 2, 3, 3, 3-heptafluoropropane) in the atmosphere, Atmospheric chemistry and physics, 10, 5903-5910, https://doi.org/10.5194/acp-10-5903-2010, 2010.

Laube, J. C., Newland, M. J., Hogan, C., Brenninkmeijer, C. A. M., Fraser, P. J., Martinerie, P., Oram, D. E., Reeves, C. E., Röckmann, T., Schwander, J., et al.: Newly detected ozone-depleting substances in the atmosphere, Nature Geoscience, 7, 266-269, https://doi.org/10.1038/ngeo2109, 2014.

Laube, J. C., Mohd Hanif, N., Martinerie, P., Gallacher, E., Fraser, P. J., Langenfelds, R., Brenninkmeijer, C. A., Schwander, J., Witrant, E., Wang, J.-L., et al.: Tropospheric observations of CFC-114 and CFC-114a with a focus on long-term trends and emissions, Atmospheric Chemistry and Physics, 16, 15 347-15358, https://doi.org/10.5194/acp-16-15347-2016, 2016.

Oram, D., Mani, F. S., Laube, J., Newland, M., Reeves, C., Sturges, W., Penkett, S., Brenninkmeijer, C., Röckmann, T., and Fraser, P.: Long-term tropospheric trend of octafluorocyclobutane $\left(\mathrm{c}-\mathrm{C}_{4} \mathrm{~F}_{8}\right.$ or PFC-318), Atmospheric Chemistry and Physics, 12, 261-269, https://doi.org/10.5194/acp-12-261-2012, 2012.

Riahi, K., Rao, S., Krey, V., Cho, C., Chirkov, V., Fischer, G., Kindermann, G., Nakicenovic, N., and Rafaj, P.: RCP 8.5-A scenario of comparatively high greenhouse gas emissions, Climatic Change, 109, 33, https://doi.org/10.1007/s10584-011-0149-y, 2011.

Van Vuuren, D. P., Edmonds, J., Kainuma, M., Riahi, K., Thomson, A., Hibbard, K., Hurtt, G. C., Kram, T., Krey, V., Lamarque, J.-F., et al.: The representative concentration pathways: an overview, Climatic change, 109, 5, https://doi.org/10.1007/s10584-011-0148-z, 2011. 